\title{
OUR MOST IMPORTANT PROBLEM
}

\author{
JAMES A. F. STONER \\ Gabelli School of Business, Fordham University \\ New York, New York, U.S.A. \\ stoner@fordham.edu
}

In 1986, widely honored scientist and intellectual innovator Richard Hamming gave a talk at the Bell Labs Morris Research and Engineering Center in Morristown, N.J. where he recalled a series of lunches at one of the labs. During those lunches he began asking, "'What are the important problems of your field?' And after a week or so, 'What important problems are you working on?' And after some more time (he) came in one day and said, 'If what you are doing is not important, and if you don't think it is going to lead to something important, why are you at Bell Labs working on it?'" (Hamming, 1986).

Hamming's questions need not be limited to scientists at one of the world's greatest research institutions of all time. "What is the most pressing problem facing us today? Are we working on it? If we are not working on it, why are we not doing so?"- these words might be appropriate for each of us in the short amount of time we are blessed with to be on this beautiful planet.

Given the history of the Jesuits and their tradition of "changing the world" through education inspired by repeated social innovations (Lowney, 2003), Jesuit universities and their business schools are especially called upon to explore such questions and to discover, in doing so, the most important problem facing us. Indeed, Pope Francis in Laudato Si' (Francis, 2015) seems to have little doubt about the most pressing challenge that we all, including our very species itself, face. He is asking us-in an encyclical that is unusual in its being addressed not just to Catholics or Christians but to everyone on this planet-to engage in dialogue about the already demonstrably harmful and potentially catastrophic economic, environmental, social, and cultural course we as a species are embarked upon. And to discover, from that dialogue, how we can make our own special contributions toward improving the trajectory of our current actions. 
A year after Laudato Si' was published, Nobel laureate Paul Krugman also seemed to have little doubt about the most pressing problem we are facing, especially if we consider global policy issues to be indicators of important concerns for our species: "Last year was the hottest on record, by a wide margin, which should-but won'tput an end to climate deniers' claims that global warming has stopped. The truth is that climate change just keeps getting scarier; it is, by far, the most important policy issue facing America and the world" (Krugman, 2016).

A few months ago, Bill McKibben, one of our long term "canaries" in the "coal mine" of global unsustainability and author of many books including The End of Nature (1989) and Eaarth: Making a Life on a Tough New Planet (2010), asked the scary question "Has the human game begun to play itself out?" in the subtitle of his new book, Falter (2019). Jared Diamond, perhaps best known for his Guns, Germs, and Steel: The Fates of Human Societies (1999) and author of Collapse: How Societies Choose to Fail or Succeed (2005), provided a review of McKibben's book in an April 21, 2019 New York Times Book Review article. He observed that

in the first half of the book, [McKibben] explains the present dangers to civilization, which include the risk of nuclear war and multiple hazards associated with climate change: increasing atmospheric carbon dioxide, threats to food production, rising sea levels, and ocean warming and acidification.

\section{Diamond then notes that}

the middle part of the book discusses forces opposing solutions to the problems laid out in the first part-motivated variously by self-interest, grim realities, power, ideals and views about the proper role of government. These forces include Exxon, poverty, inequality, Ayn Rand, the Koch brothers, other very rich Americans, President Trump and Silicon Valley....

Finally, in the book's last section, McKibben offers his reasons for hope. Foremost among these are solar panels, which are making cheap renewable energy available around the world, and nonviolent movements, whose successful practitioners against entrenched, well-armed oppositions have included Gandhi, Martin Luther King Jr., Earth Day demonstrators and McKibben's own group, 350.org.

Diamond concludes his rich and valuable review with the following paragraph:

It will take many different voices to persuade the world's diverse citizens and corporations to collaborate on solving the world's biggest problems. 
McKibben's voice has been an influential one. My hope is that his new book will strengthen the motivation of those already sympathetic to his views. My fear is that it won't convince many who remain hostile to them. I hope that my first prediction proves right, and that my second proves wrong. (Diamond, 2019)

The following week, John Lanchester (2019) wrote that climate change "is the greatest challenge humanity has collectively faced" in the first sentence of his Times review of two other new books (Wallace-Wells, 2019; Rich, 2019).

\section{SO WHAT?}

In addressing the realities of our recent, current, and likely future situations, the editorials and articles of the Journal of Management for Global Sustainability have frequently called for us, in the words of Jim Collins, "to confront the brutal facts, yet never lose faith" (Collins, 2001) and will continue to do so, and perhaps even more strongly and stridently in the future.

The scary thing about perspectives that suggest that climate change and global unsustainability are "existential threats" is that we are not talking about the writings of authors such as Camus, Kierkegaard, and Sartre; we are talking about threats to the very existence of our species as a species. One of the major contributions of Laudato Si' is how Pope Francis states, both forthrightly and directly, that global unsustainability is a moral issue and that the damages we are doing today to the most vulnerable and to future generations across time are moral failings of the greatest magnitude. The ways that we have chosen for producing and consuming the necessities and luxuries of our lives and how we distribute the benefits and costs of those production-consumption-distribution processes all contribute to the unsustainable nature of our current situation. We are all part of the problem of global unsustainability, and business schools are no exception-they, too, are part of the problem.

The clear emphasis of Laudato Si' on the immorality of our contributions toward creating an unsustainable present for many and an unlivable future for all is pertinent to the current state of teaching, research, and conceptualization of members of Jesuit business schools in particular. Indeed, even if Jesuit business education may be slightly better than average when it comes to addressing 
questions of global unsustainability, it would be difficult to defend the assertion that the dominant teaching in marketing, finance, and accounting in Jesuit business institutions is very different from that found in other schools. The occasional course in green marketing or marketing to the "bottom of the pyramid" aside, it would be very hard to claim that courses in finance, marketing, accounting, economics, management, operations, communications, negotiation, law, and perhaps even ethics in all business schools, including Jesuit ones, are not devoted primarily to giving our students the skills and attitudes to "take-make-waste-faster-and-fasterfor-the-richer-and-richer" — and to feel very good about themselves as they do so.

In recognizing that global unsustainability is, at its very core, a moral problem of the greatest magnitude and not just a business concern, all universities and their business schools have the obligation and opportunity to conduct themselves in ways that will make them stop adding to the problem and start becoming vehicles for solutions. The worldwide network of Jesuit business schools, in particular, is especially called upon to explore the realities of our current situation, reflect upon those realities and our resources for making positive contributions, and take actions that might impact not only educational institutions but also the world.

Arthur Taylor, when he was dean of Fordham University's Graduate Business School from the late 1980s to early 1990s, once invited Roland Christensen, the master of case teaching at the Harvard Business School, to join a faculty retreat and lead a session on case teaching. Frank Werner, who had been one of Christensen's students at HBS, was asked to host Christensen during the visit.

At the end of the trip, Frank observed to Roland, as he was driving the latter back to the airport for his return flight, that he must receive many such invitations, and asked why he accepted this one. Christensen replied that Frank was correct about the invitations and that he had asked his dean if he should accept this one when it came in. His dean said yes, that it would be good to accept because one area in which HBS might be competitively vulnerable was that which was somehow related to the deepest purpose and meaning of business organizations and education-an area to which spirituality and religion might have special access. He was curious, therefore, what Fordham might be doing as a faith-based business school in an area where HBS might be vulnerable. 
When Frank asked Roland what he had learned during his visit about what Fordham was doing in such a domain, Christensen replied, "Not much."

Fordham, unfortunately, was not leveraging its core Jesuit values and heritage to pioneer the transformation of business education and research. Indeed, in terms of innovation for the transformation of business education, Christensen's reply was probably true for essentially all business schools-faith-based and otherwise. And it probably is still true today, when the need for business education transformation is even greater in our much more serious situation.

Three decades after that Christensen-Werner conversation, the need for deep transformations, driven by global unsustainability, in what and how we produce, distribute, and consume as suggested in Laudato Si' offers many opportunities for Jesuit business schools to provide dramatically different answers to the question that Roland Christensen was exploring. Answers that just might light the fire that transforms business education around the world.

\section{NOW WHAT? A SECOND CHANCE FOR JESUIT BUSINESS SCHOOLS}

Jesuit business schools have, in a number of very significant ways, pioneered approaches and actions that have actively contributed and continue to contribute toward a more just and sustainable world. Commitments to social justice and the alleviation of poverty, for instance, have long been major foci across virtually all of Jesuit business education. Centers and programs for global sustainability are located on a number of campuses, and the schools have been outstanding leaders in the domains of social innovation and social entrepreneurship. The International Association of Jesuit Business Schools (IAJBS) made a deep commitment to global sustainability in 2009. Although the many other such activities are too numerous to list here and should not be minimized or overlooked, other exciting opportunities still lie ahead and are yet to be seized; three of these are discussed next. While they are attractive for the member schools and faculty of the IAJBS and CJBE (Colleagues in Jesuit Business Education) in particular, they nevertheless present exciting opportunities for all business schools. After discussing these three areas of opportunity, we will provide a short introduction to the articles in this issue of the Journal. 


\section{THE IAJBS WORLD FORUM}

The IAJBS recognized this existential threat ten years ago when its $15^{\text {th }}$ World Forum met at the Xavier Labour Relations Institute (XLRI) in Jamshedpur, Jharkhand, India. That World Forum, the theme of which was leadership for sustainability, was different in one major and perhaps almost unique aspect-a resolution submitted, passed unanimously, and ratified the next day by the Executive Board of the IAJBS. The resolution called for the World Forum to devote itself for the next ten years to the broad theme of contributing toward a more sustainable world. Then, at the World Forum at Ateneo de Manila University in Manila the following year, Rudy Ang and his IAJBS colleagues suggested that the organization might create a journal on sustainability. The first issue of that journal, the Journal of Management for Global Sustainability, appeared in 2013.

Over the past decade since 2009, the words used to describe the goal of achieving a sustainable world have evolved roughly along the lines of sustainability, sustainable development, global sustainability, and flourishing. Now, perhaps, we may add "regeneration," which refers not just to doing less harm or no harm at all but actually to restoring our broken world- "healing our common home," as Pope Francis might say. The definition of sustainability offered in the first issue of this journal, interestingly enough, explicitly addressed the need for "healing our broken world" by substituting the words "without compromising" as found in the popular Brundtland Commission definition of sustainable development with "while enhancing."

We define global sustainability as ... a process that meets the needs of the present generation while enhancing the ability of future generations to meet their own needs. Global sustainability envisions a world that works for everyone with no one left out. (Stoner, 2013: 2)

The $25^{\text {th }}$ World Forum will meet in July 2019, this time at the Xavier Institute of Management (XIMB) in Bhubaneswar, India. It will also serve as the inaugural South Asia Regional Chapter Meeting of the Colleagues in Jesuit Business Education. The theme of this Forum, "Innovate and Flourish," honors John Ehrenfeld's early definition of sustainability as "the possibility that human and other life will flourish on the planet forever" (Ehrenfeld, 2009). 
Given that the 2019 meeting falls on the tenth anniversary of the commitment made at the XLRI conference in 2009 , it is very likely that a new resolution inviting the World Forum to recommit itself to another ten years of leadership for a sustainable world-or perhaps to commit to a regenerative one-will be offered.

The IAJBS World Forum is, of course, not the only annual conference that had historically chosen a new and different theme each year. Almost all conferences, in fact, do exactly that. However, just as the World Forum "put a stake in the ground" by committing itself for ten years to the theme of leadership for sustainability, other professional organizations or even major foundations can make similar commitments to focus both their and our energies on "humanity's greatest challenge." In the domain of professional organizations for management academics alone, for example, the Academy of Management, Eastern and other regional Academies of Management, Management and Organizational Behavior Teaching Conference, and others could send the signal to the world that the issues of climate change and global unsustainability must no longer be ignored and that their members are going to give these the attention they have long deserved but not received. And perhaps major foundations, too, like the Bill \& Melinda Gates Foundation, MacArthur Foundation, Ford Foundation, Susan Thompson Buffett Foundation, and others will make similar deep and longer-term commitments to marshal the resources we need to inspire, fund, and honor those who are willing and eager to do what must be done if we and our children are to have a future worth having.

\section{TRANSFORMING OURSELVES AND BUSINESS EDUCATION}

If we look for two major transformations that our species might need for dealing with our current situation of global unsustainability, for moving toward a flourishing and regenerative future, one of those might be at the individual and the other at the systems level. As individuals, we may need to undertake the "ecological conversion" that Pope Francis calls for in Laudato Si'. We may need to become different people as producers, consumers, and citizens. At the systems level, we may need to transform the broken producing-distributing-consuming system that serves so much of the world so poorly even as it is destroying the capacity of the planet to support our own and other species. 
How are we to bring about these transformations? The network of Jesuit business schools could provide valuable contributions to the world in both of these domains.

\section{EXPLORING TECHNOLOGIES FOR ECOLOGICAL CONVERSION}

There may be some irony in the fact that we are investing billions and billions of dollars to investigate a variety of technologies for addressing the problems of our producing-distributing-consuming system but almost nothing to explore how we can become the kinds of people who will use those technologies to create a sustainable/flourishing/regenerative world. We are simply not making large-scale investments to discover how we can transform ourselves; in fact, we are making hard technology investments at the systems level at a time when many observers believe we already have all the technology we need to create a sustainable world (e.g., the 100 projects described in Paul Hawken's Drawdown: The Most Comprehensive Plan Ever Proposed to Reverse Global Warming [2018] and the integrated approach to transforming the global economy using existing technologies as described in A Finer Future: Creating an Economy in Service to Life by Lovins, Wallis, Wijkman, \& Fullerton [2018]). The problem is that we are simply not using the technologies we already have.

If we free ourselves from automatically thinking of technology as something mechanical, often embodied in machinery, and directed toward producing physical products and instead remember that we can define it simply as "a process for getting something done" or as "a system by which a society provides its members with those things needed or desired" (Your dictionary, n.d.), we may find ourselves called to accept the invitation to invest substantively in figuring out how to use our existing centuries- and millennial-old technologies of personal transformation more effectively as well as discover new ones.

We can look for ways in which we can make those technologies of transformation more effective, rapid, and joyful for those sharing, acquiring, and using them. And we can look for ways to invent brand-new ones. We might note, for instance, that the spiritual exercises of St. Ignatius, something close to home for Jesuit institutions, can be looked at as a five-century-old technology of personal and spiritual transformation, one that has proven itself over and over again. The temptation to explore very promising technologies of personal transformation can 
therefore be quite appealing given so many billions already being invested in the search for systems level technologies aimed at changing our ways of producing, distributing, and consuming.

When we focus on ourselves and our ways of being in the world, it is also tempting to think of investing appreciable monies in the creation of a series of innovative research centers that would look into technologies of personal transformation. CARTT (Centers for Action and Research into Transformational Technologies) is almost certainly a label that can be greatly improved; nevertheless, whatever we choose to call the endeavor, it might be valuable to look, through the lens of technology, at well-established and powerful transformational experiences such as the Spiritual Exercises of St. Ignatius, yoga, meditation, mindfulness practices, appreciative inquiry, the Ashoka $U$ set of campus programs and initiatives, Landmark Education's set of programs, and many, many others that provide profound and lasting positive change in people's lives and ways of being in the world. And then there are emerging approaches that may also be worthy of serious exploration, such as Theory U (e.g., Scharmer, 2016), Humanistic Management (e.g., Pirson, 2017), and Quantum Leadership (Tsao \& Laszlo, 2019).

There is a nascent possibility that one or more such centers might get started soon. Indeed, it might be particularly appealing to explore technologies of personal transformation at faith-based universities, both Jesuit and otherwise, given that so many of these centuries-old technologies for transforming ourselves as human beings arise from and/or are grounded in spiritual ways of being in the world. Faith-based universities might be particularly at home providing leadership in discovering what makes these technologies have the impact they have, how we can make them available to more and more of the world's peoples-how we can make them cheaper, faster, better-and, very importantly, how we can protect ourselves from and prevent their misuse.

\section{BUSINESS SCHOOL LEADERSHIP}

In "Torn Between Two Paradigms: A Struggle for the Soul of Business Schools," Chris Laszlo, Robert Sroufe, and Sandra Waddock (2017) call for taking action in transforming the neoliberal narrative that dominates, to a very large extent, the teaching of business around the world. As has been noted in this 
journal and elsewhere, the all-pervasive, self-reinforcing, internally-consistent, and environmentally-destructive global system of producing, distributing, and consuming is so well entrenched and so fully integrated within itself that it seems impervious to any efforts at changing it. However, since it is also so complex and interconnected, there are a seemingly endless number of places where the system can be entered into and hopefully disrupted for positive ends.

With the objective of turning business education into a vehicle for transforming our whole global producing-distributing-consuming system, the IAJBS/CJBE application to the 2016 MacArthur Foundation 100\&change competition was just one of many possibilities. On June 2, 2016, the MacArthur Foundation announced a $\$ 100$ million competition to solve a major societal problem. The possibility of the Jesuit business schools joining the competition was discussed briefly during the July 10 business meeting of the CJBE at Le Moyne College in Syracuse, New York. A week later, at the $23^{\text {rd }}$ IAJBS World Forum in Nairobi, Kenya, the following resolution was passed unanimously and approved the next day by the Executive Board of the IAJBS:

The annual meeting of the IAJBS requests the IAJBS leadership, CJBE leadership, and the rest of the network of Jesuit business schools to work together to apply for the MacArthur Foundation 100 million dollar 100\&change competition with a project to transform Jesuit business education to be fully aligned with the wisdom in Laudato Si', with our universally-valid Jesuit educational tenets, and with the need for global sustainability, social justice, and poverty alleviation. (July 18, 2016)

On October 2, 2016, a proposal to use the transformation of Jesuit and all business education as a vehicle for transforming our global producing-distributingconsuming system was submitted to the MacArthur Foundation. There is a bit of ambiguity concerning how the various applications are counted, but by one count the number is 1,407. On this count, the IAJBS/CJBE application was one of the 1,406 applications that did not win the $\$ 100$ million prize.

The submission deadline for entries to the 2019 100\&change competition is in August 2019. Efforts are currently being made to put together a new application that is very similar to the original 2016 one. This new application will continue to invite Jesuit and other business schools to transform their curricula and much of their research by aligning them with the realities of the $21^{\text {st }}$ century and the need 
for a regenerative world. Indeed, the possibility of such an application has already been described in this journal (Stoner, 2018).

It would not be necessary for a faculty member to be in a university that wins the MacArthur Foundation prize - a highly unlikely event—-to make a contribution toward transforming business education and our global producing-distributingconsuming system. Any teacher in any of the business school disciplines can look at her or his syllabus with a view toward deciding what is appropriate for the realities of the $20^{\text {th }}$ century versus what is appropriate for those of the $21^{\text {st }}$, and then start making the kinds of teaching and research adjustments that the realities of the $21^{\text {st }}$ century call for. Faculty members at Regis University's Anderson College of Business and at Fordham's Gabelli School of Business are, in fact, either starting or have long been engaged in exactly this type of inquiry. Given that it is difficult to defend teaching from a syllabus that is appropriate for the $20^{\text {th }}$ century and not the $21^{\text {st }}$, it is highly likely that many others will follow suit by exploring on their own and sharing what they are doing and learning with others.

\section{HOW TO MAKE A DIFFERENCE? ALMOST TOO MANY OPPORTUNITIES TO CHOOSE FROM}

As this editorial was being written, the Anderson College of Business announced a new track in its Masters of Science in Finance and Economics program in collaboration with the Capital Institute and other partners committed to exploring and creating approaches to regenerative finance on a local and a global level. The program will address exactly those problems in the global financial system that are such a barrier to creating a sustainable/flourishing/regenerative world.

There are many opportunities for each of us in what we teach, what we research, how we define service, what we choose to purchase-or rent-and consume, what we invest in, and how we vote. The hard questions are not about finding opportunities and challenges but in choosing from among many attractive alternatives. And about how much of our time, energy, and other resources we will devote to the selections we make.

We know what the problem is. The question is what each of us will do about it. 


\section{AND NOW TO THE ARTICLES IN THIS ISSUE OF THE JOURNAL}

Each of the five articles in this issue provides ways by which change and transformation on the personal and/or systems levels can contribute to a more sustainable world.

Bernard Arogyaswamy argues that while innovation often creates competitive advantage and economic growth, it can also have negative impacts, e.g., placing burdens on already limited resources, environmental damage, social inequalities, and even diminished social mobility. In describing how innovation strategies can be designed and chosen for contributing more effectively to the creation of a sustainable world and how sustainability-focused actions can actually be a source of innovation, he develops a three by four matrix that offers a framework for creating and analyzing sustainability-focused initiatives and ideas. He places product, process, and managerial innovation on one axis and four sustainability approaches (cost reduction and differentiation-focused actions for environmental sustainability; employee and community-directed actions for social sustainability) on the other. The result is an array of 12 sustainability strategies that corporations can use as guides for achieving goals like lowered emissions, less material wastage, and greater employee wellbeing and community welfare, among others.

To help in the shift toward renewable energy, Claire Siegrist and Evangelos Katsamakas present the results of a business education research project that looked into the question of electricity generation using a distributed system based on renewable energy vis-à-vis a centralized one based on fossil fuels. They describe a decision support system that can help policymakers and stakeholders assess the feasibility of solar energy systems for rooftops. The system uses metrics based on existing regional assessment models and which include information on variables such as costs to consumers, regional demand, and government support. The paper thus shows how to estimate costs and amounts of electricity generated to see how a renewable energy system might perform against traditional fossil fuels and how it might reduce overall emissions. Use of the support system can therefore lead to actions that will help reduce costs and emissions even if distributed generation may not entirely replace centralized systems as of yet.

Another tool that is the result of a business education project comes from the work of Karyl Leggio and Col. Reid Nichols. Students used Monte Carlo simulation 
(a technique that is often used to understand risk) as a financial modeling device for supporting decisions on how to allocate resources and justify costs related to the Chesapeake Bay Interpretive Buoy System, a network of buoys that provides users with the technical and scientific information needed to "improve marine forecasts" and "monitor the health of the [Chesapeake] Bay." The resulting tool handled enough complexity and had sufficient substance that it was used by the National Oceanic and Atmospheric Administration (NOAA) in its budget request to Congress. It was seen as particularly useful for assisting NOAA in its task of protecting and preserving Chesapeake Bay, an important source of seafood and the home of a major port on the east coast of the United States.

The work of Quan Le and Grace Jovanovic emphasizes the importance of partnerships in transforming individual lives and moving trading systems toward the creation of more sustainable outcomes. Using a trade model in which coffee is bought directly from Nicaraguan farmers at fair prices that respect previously established price floors, the student-founded Café Ambiental provides its coffee producers with economic stability and encouragement. This in turn allows the farmers to transition to organic farming while improving the health, education, and economic well-being of their families. The students and faculty working in this partnership with the farmers, on the other hand, experience aspects of personal transformation through business and life lessons that are consistent with the goal of solidarity with the marginalized.

Acknowledging the many ways by which progress in the sharing economy can contribute to a more sustainable world, Alain Decrop and Antje Graul tackle the challenge of improving the participation of providers in said economy through collaborative consumption schemes which can lead to less waste, reduction of new purchases, and enhanced recirculation of products. Their study presents evidence that both reduced perception of risk and enhanced system trust can improve the likelihood of participation in a sharing platform. Consumers are more willing to share their assets as providers in what the authors call a "reciprocal (monetary) compensation" arrangement rather than in a "generalized reciprocity" setup because they perceive a higher degree of risk with the latter-they have no guarantee of "what they are getting in return" in the generalized reciprocity situation. The authors also show that these collaborative consumption schemes are more attractive when a not-for-profit market intermediary facilitates the sharing process. It is 
therefore important to understand these aspects of the sharing economy as such and to take action on them if the supply of shared assets is to grow, meet the increasing demand for sharing resources, and achieve the advantages of doing so.

Indeed, as these projects inspired by business education suggest, there are likely to be many other examples in our business schools that can nudge us into action toward creating a more sustainable, flourishing, and regenerative world, whether they help us make decisions on an organizational and systems level or inspire us on a personal one.

\section{POST SCRIPT}

For those of us, by the way, who are tempted to ask the kinds of questions that Hamming did, he concluded his description of those Bell Labs lunches with the following punchline:

"I wasn't welcomed after that; I had to find somebody else to eat with!"

\section{REFERENCES}

Collins, J. 2001. Good to great: Why some companies make the leap ... and others don't. New York: HarperBusiness.

Diamond, J. 1999. Guns, germs, and steel: The fates of human societies. New York: Norton.

Diamond, J. 2005. Collapse: How societies choose to fail or succeed. New York: Viking/Penguin.

Diamond, J. 2019. How it ends: The fate of the planet hangs in the balance. How do we avoid the worst-case scenario? The New York Times Sunday Book Review, April 21: 13.

Ehrenfeld, J. 2009. Sustainability by design: A subversive strategy for transforming our consumer culture. New Haven, CT: Yale University Press. 
Francis. 2015. Laudato si': On care for our common home. Vatican City: Libreria Editrice Vaticana.

Hamming, R. 1986. You and your research. Transcript of the Bell Communications Research Colloquium Seminar (March 7). Available at https://www.cs.virginia. edu/ robins/YouAndYourResearch.html (accessed April 23, 2019).

Hawken, P. (Ed.). 2018. Drawdown: The most comprehensive plan ever proposed to reverse global warming. New York: Penguin.

Krugman, P. 2016. Wind, sun and fire. The New York Times, February 1. Available at https://www.nytimes.com/2016/02/01/opinion/wind-sun-and-fire.html (accessed April 22, 2019).

Lanchester, J. 2019. World on fire. The New York Times Sunday Book Review, April 28: $1,20$.

Laszlo, C., Sroufe, R., \& Waddock, S. 2017. Torn between two paradigms: A struggle for the soul of business schools. AI Practitioner, 19(2): 108-119.

Lovins, L. H., Wallis, S., Wijkman, A., \& Fullerton, J. 2018. A finer future: Creating an economy in service to life. Gabriola, BC: New Society Publishers.

Lowney, C. 2003. Heroic leadership: Best practices from a 450-year-old company that changed the world. Chicago: Loyola Press.

McKibben, B. 1989. The end of nature. New York: Random House.

McKibben, B. 2010. Eaarth: Making a life on a tough new planet. New York: Times Books/Henry Holt.

McKibben, B. 2019. Falter: Has the human game begun to play itself out? New York: Henry Holt.

Pirson, M. 2017. Humanistic management: Protecting dignity and promoting wellbeing. New York: Cambridge University Press.

Rich, N. 2019. Losing earth: A recent history. New York: Farrar, Straus, \& Giroux. 
Scharmer, O. 2016. Theory U: Leading from the future as it emerges: The social technology of presencing (2nd ed.). Oakland, CA: Berrett-Koehler.

Stoner, J. A. F. 2013. What we want this journal to be: Our first editorial essay in which we hope to start a continuing and evolving conversation about why we are now creating this new journal and what we want it to become. Journal of Management for Global Sustainability, 1: 1-6.

Stoner, J. A. F. 2018. Innovation in educational and societal transformation: The MacArthur Foundation, Jesuit business schools, and the world. Journal of Management for Global Sustainability, 6(2): 19-35.

Tsao, F. C., \& Laszlo, C. 2019. Quantum leadership: New consciousness in business. Redwood City, CA: Stanford University Press.

Wallace-Wells, D. 2019. The uninhabitable earth: Life after warming. New York: Tim Duggan Books/Crown Publishing.

Your dictionary. n.d. Technology. Available at https://www.yourdictionary.com/ technology (accessed April 23, 2019). 